\title{
1. Conceptualizing climate migration
}

\section{ABSTRACT}

No simple adjustment in international law can provide an adequate response to the issues raised by the current debates on climate migration. Yet, these discussions could stress the need for structural reforms in global governance in a growingly interdependent world. This introduction presents an overview of the central themes of this book. It introduces the main methodologies and theoretical frameworks that form the general background for the following analysis.

\section{INTRODUCTION}

Policy making is often a process of creating intellectual puzzles, getting into intellectual binds, and then extracting people from these dilemmas. ${ }^{1}$

Extensive media coverage has defined climate migration as one of the major humanitarian causes of our time. In order to capture international attention, the government of the Maldives organized an under-water cabinet meeting, suggesting what could happen to this archipelagic country as sea level continues to rise. ${ }^{2}$ In 2005, The Guardian identified the resettled inhabitants of the Carteret Islands, in Papua New Guinea, as the "first climate change refugees." 3 This made little of the fact that the relocation of this community had been under consideration for decades, long before evidence of climate change impacts. ${ }^{4}$ American media turned to a small Alaskan village, Kivalina, which has been exposed to more storm surges and erosion as the ice that formed on its shore melted; in 2007, the resettled villagers were considered by the New York Times as

1 John Kingdon, Agendas, Alternatives, and Public Policies, 2nd ed. (Harper Collins College, 1995) at 126.

2 "Maldives Cabinet makes a Splash," BBC (17 October 2009).

3 John Vidal, "Pacific Atlantis: First Climate Change Refugees," The Guardian (25 November 2005).

4 Scott Leckie, "Introduction" in Scott Leckie, ed., Land Solutions for Climate Displacement (Routledge, 2014) 1 at 17. 
"among the first climate refugees in the United States."5 In March 2009, the same newspaper published a series of five articles describing, through the example of Bangladesh, "mass migration spurred by climate change" as nothing less than "a migration that will change the face of the world."

Robert Redford justly called Michael Nash's documentary, Climate Refugee, "an agent for social change."7 The attribution of migration to climate change relates to normative arguments calling the international community to do something to protect "climate migrants" - although there are different opinions about what exactly should or could be done. As will be shown, the discussion on climate migration inevitably raises larger issues in global governance, ranging from the lack of international cooperation in the realization of economic and social rights, to the unfulfilled responsibility of greenhouse gas emitters for the adverse effects of climate change. No simple adjustment of existing international law or institutions can suffice to provide an adequate response to the issues flagged by the debate on climate migration. Rather, a profound transformation of some international institutions is a necessary component of any complete "solution," and may call for re-conceptualizing the interests of states in an increasingly interdependent world.

The following pages provide an overview of the central themes and arguments of this book, before introducing central theoretical frameworks. The first section discusses the identification of environmental changes as a factor of human mobility. The second section points out to some flaws inherent to the concept of "climate migration," but it argues that the debate might nevertheless be worth pursuing. Lastly, the third section suggests some ways of analysing the argumentative leverage of the concept of climate migration and it presents the general thread of this book.

5 William Yardley, "Alaskan Town Seeks Lifeline amid Climate Change" New York Times (27 May 2007).

6 Lisa Friedman, "Coming Soon: Mass Migrations Spurred by Climate Change", New York Times (2 March 2009); "Flooding, Food and Climate Change in Bangladesh" (9 March 2009); "Climate Migrants Flock to City in Bangladesh" (16 March 2009); “A Global 'National Security' Issue Lurks at Bangladesh's Border" (23 March 2009); "Bangladesh Needs the West's Help, But Isn't Waiting for It" (30 March 2009).

7 Dorothy Spears, "Film on Climate Refugees Strikes a Chord," Green: A Blog about Energy and the Environment (12 August 2011). 


\section{I. "NEW” FACTORS OF MOBILITY}

It appears that geography ... is the basis of history in a way that is not generally recognized; and ... climatic changes have been one of the greatest factors in determining the course of human progress. ${ }^{8}$

People have always been moving, and each society comprises migrants we are all either migrants or descendants of migrants. There is no simple story to explain why, at a specific time, some people move while others do not. Political, ethnic and religious oppression, economic downturn and demographic pressure are among the factors that contribute to "push" migrants from their place of origin, whereas economic opportunities, socio-cultural representations and individual hopes may "pull" us toward particular destinations. Perceived costs and risks associated with migration also exert an influence on human mobility, although governments have never succeeded entirely in controlling desperate migrants in the presence of compelling "push" factors and in the absence of an alternative safe destination. Beyond these general considerations, individual inclinations also play a role for which no theory can give a full account. ${ }^{9}$

On the other hand, the human environment has constantly been changing as a result of natural or man-made forces, even though current anthropogenic climate change will induce greater and faster change at a global scale in the coming decades, and mobility has always been a process through which human societies have adjusted to changes in their physical environment. Changes in our environment may "push" us to migrate either by directly threatening our conditions of survival, or, more subtly, by affecting our basic living conditions or our sources of livelihood, particularly in the case of resource-dependent economic activities such as agriculture and fishing. Environmental changes may also attract us to new destinations which provide better living conditions or new economic opportunities. More complex and indirect causal

8 Ellsworth Huntington, The Pulse of Asia: A Journey in Central Asia Illustrating the Geographic Basis of History (Houghton, 1907) at 359.

9 Among a wide body of theoretical literature trying to explain why some people migrate (or, more rarely, why others do not), see in particular Arthur Lewis, "Economic Development with Unlimited Supplies of Labor" (1954) 22 The Manchester School 139; Michael Todaro, "A Model of Labor Migration and Urban Unemployment in Less Developed Countries" (1969) 59 Am. Econ. Rev. 138; Everett Lee, "A Theory of Migration" (1966) 3:1 Demography 47; Thomas Faist, The Volume and Dynamics of International Migration and Transnational Social Spaces (O.U.P. 2000); Stephen Castles, "The Forces Driving Global Migration” (2013) 34 J. Intercultural Stud. 122. 
pathways are for instance at play when resource scarcity exacerbate conflicts or when measures taken in response to changing environmental constraints involve displacement or resettlement programs.

\section{A. (Re)-conceiving Environmental Factors of Migration}

While the relevance of environmental conditions as a factor of migration was duly recognized in early theoretical works on human mobility developed during the late 19 th and early 20 th centuries, ${ }^{10}$ it was largely disregarded during most of the 20th century. This neglect relates partly to the "rise of an economic paradigm in migration theory," but even more to "the Western idea that progress implies a decreasing impact of nature on human fare."11 One of the few theories that considered "a movement related to man's inability to cope with natural forces," in 1958, qualified it as "primary migration"12 - hence not a direct concern for the then self-proclaimed "civilized nations."

Environmental factors of migration came back to the fore in the late 1980s, prompted by a trend of politically-engaged research on to the plight of those displaced because of degrading environmental conditions. ${ }^{13}$ The initiative came not from migration scholars, but from environmentalists, as part of a historical trend toward the realization of the environmental impacts of industrial societies. At that time, the "extent and severity of worldwide environmental conditions" 14 was best exemplified by the 1986 Chernobyl nuclear disaster, although a relation was also made with climate change, sea-level rise and desertification. ${ }^{15}$ Late British environmentalist Norman Myers predicted the apparition of large

10 See in particular E.G. Ravenstein, "The Laws of Migration" (1889) 52:2 J. Royal Statistical Society 241 at 286; Ellen Semple, Influences of Geographic Environment, on the Basis of Ratzel's System of Anthropo-geography (Holt, 1911) at 110-11 (noting the "paucity of resources and isolation have generally insured to a region a peaceful history; natural wealth has always brought the conqueror").

11 Etienne Piguet, “From 'Primitive Migration' to 'Climate Refugees': The Curious Fate of the Natural Environment in Migration Studies" (2013) 103:1 Ann. Association Am. Geographers 148 at 151.

12 William Petersen, "A General Typology of Migration" (1958) 23:3 Am. Sociological Rev. 256 at 259.

13 Essam El-Hinnawi, Environmental Refugees (UNEP, 1985); Jodi Jacobson, Environmental Refugees: A Yardstick of Habitability (Worldwatch Institute, 1988).

14 Ibid., at 7.

15 See ibid., at 5. 
numbers of "environmental refugees" - 150 million (1993), ${ }^{16} 200$ million (2002), ${ }^{17}$ or 250 million (2007) $)^{18}$ - in a series of studies which played a great role in setting the issue on research agendas but were thereafter largely rejected as based on no solid definition or science.

While migration scholars soon came to an agreement that environmental conditions have an influence on human mobility, they unanimously denounced the "alarmist" discourse of the environmentalists and insisted on the inclusion of environmental factors within a larger cluster of causes. ${ }^{19}$ The notion of "environmental refugees," in particular, failed to distinguish between internal and international, temporary and permanent, forced and voluntary migrants. Forming what would be called a "sceptical" school, migration scholars insisted on the interaction of environmental factors with economic, social, political and demographic circumstances. They showed that environmental factors have most often an indirect influence, particularly through economic dynamics, for instance when drought or land salinization decrease agricultural yield. Environmental factors were reconceived as inducing rather than necessarily forcing individuals to migrate: mobility generally takes place on a continuum between coercion and choice. Migration scholars also insisted that most of the migratory impact of environmental changes would be on internal mobility rather than international migration. While denouncing the alarmists' rather simplistic representations of the relation between environment and migration, however, the "sceptics" did not in any way deny the relevance of environmental factors of human mobility.

16 Norman Myers, "Environmental Refugees in a Globally Warmed World" (1993) 43:11 BioScience 752.

17 Norman Myers, "Environmental Refugees: A Growing Phenomenon of the 21st Century" (2002) 357 Philosophical Transactions B 609.

18 Interview of Norman Myers, reported in Christian Aid, Human Tide: The Real Migration Crisis (2007) at 48.

19 E.g. Gaim Kibreab, "Environmental Causes and Impact of Refugee Movements: A Critique of the Current Debate" (1997) 21 Disasters 20; Richard Black, Environmental Refugees: Myth or Reality? (UNHCR Working Paper on New Issues in Refugee Research No. 34, 2001); Stephen Castles, Environmental Change and Forced Migration: Making Sense of the Debate (UNHCR Working Paper on New Issues in Refugee Research No. 70, 2002). See generally James Morrissey, "Rethinking the 'Debate on Environmental Refugees': From 'Maximalists and Minimalists' to 'Proponents and Critics"' (2012) 19 J. Political Ecology 36; François Gemenne, "How They Became the Human Face of Climate Change" in Etienne Piguet, Antoine Pécoud and Paul de Guchteneire, eds, Migration and Climate Change (Cambridge University Press (C.U.P.) 2011) 225. 
For close to two decades, the alarmists appeared to have little to respond to the sceptics' insistence for a more thorough understanding of migratory processes, and a consensus slowly emerged in favour of a rather "sceptical" analysis, ${ }^{20}$ in particular through a general recognition that "environmental migrants" could not generally be distinguished from other migrants. Thus, an influential report to the UK Foresight Programme concluded in 2011 that "the range and complexity of the interactions between [environmental, economic, social and political] drivers means that it will rarely be possible to distinguish individuals for whom environmental factors are the sole driver ("environmental migrants')." 21 This report also recognized that climate change may also impede migration by depriving individuals of their source of income necessary to invest in a migration strategy.

This rather "sceptical" consensus clearly makes it more difficult to think of policy responses to the issue of environmental migration - or even to think of "environmental migration" as a discrete issue. Conceiving an individual protection status, for instance, would obviously require, first, to distinguish individual "environmental migrants." And the very rationale for a protection specific to "environmental migrants" would soon come into question if climate change impacts appear to exacerbate pre-existing migration scenarios rather than creating new migration scenarios. Therefore, "sceptical" tenets have had great difficulties to circulate beyond the analytical sphere: simpler and more convenient alarmist ideas have remained prominent not only in the media and the political discourse, ${ }^{22}$ but also in the writings of many law and political

20 In 2009, James Morrissey noted that "far less literature comes out of the maximalist school, save from Myers who continues to cite enormous figures for environmental refugees without addressing the criticisms put forward by the minimalist school." James Morrissey, Environmental Change and Forced Migration: A State of the Art Review (Refugee Studies Centre, Oxford University, 2009) at 5.

21 Foresight, Migration and Global Environmental Change: Final Project Report (UK Government Office for Science, 2011) at 9. See also: Koko Warner, Tamer Afifi and Kevin Henry, Where the Rain Falls: Global Policy Report (Bonn: UNU-EHS, 2012).

22 See for instance Barack Obama, Remarks by US President Obama at United Nations Secretary General Ban Ki-Moon's Climate Change Summit (New York, 2009), stating that "On shrinking islands, families are already being forced to flee their homes as climate refugees." 
sciences scholars ${ }^{23}$ and, although more timidly, in some intergovernmental consultations. ${ }^{24}$

\section{B. The Indirect Influence of Climate Change}

As climate change emerged as the most pressing global (environmental) concern of our time, political discussions on the relations between environmental change and migration turned progressively to focus on "climate migration." 25 Conceptually, "climate migration" is a component of "environmental migration," where migration is specifically attributed to the environmental changes associated with anthropogenic climate change. Migrations induced by environmental phenomena unrelated to climate change, such as volcanic eruptions or tsunamis, could be considered as environmental migration but not as climate migration. By contrast, the concept of climate migration has usually been associated with human mobility related to sea-level rise, to drought and desertification, or to sudden disasters (e.g. cyclones, floods) inasmuch as they can be considered as impacts of climate change. The concept of climate migration has received greater media coverage and more political attention than environmental migration, as will be seen in the following chapters, not only because of the novelty and the currency of climate change, but also because of its ability to relate, beyond a general moral argument for solidarity among peoples, to a more specific argument on the responsibility of greenhouse gas emitters for the adverse effects of climate change.

The relevant scientific community has no doubt that our climate is changing and that this is due to human activities. The Fifth Assessment Report of the Intergovernmental Panel on Climate Change (IPCC), prepared through a transparent and inclusive process of scientific deliberations, notes that "[w]arming of the climate system is unequivocal, and since the 1950s, many of the observed changes are unprecedented over

23 See e.g. Benoît Mayer, 'Constructing 'Climate Migration' as a Global Governance Issue: Essential Flaws in the Contemporary Literature” (2013) 9:1 McGill Int'1 J. Sust. Dvlpt L. \& Pol'y 87.

24 For instance, the influential "Nansen Conference on Climate Change and Displacement in the 21st Century," held in Oslo on 5-7 June 2011, did not do away with the idea that some "environmentally displaced persons" could be identified.

25 See e.g. S. Byravan and Chella Rajan, "Providing New Homes for Climate Change Exiles" (2006) 6 Climate Pol'y 247; Frank Biermann and Ingrid Boas, "Protecting Climate Refugees: The Case for a Global Protocol" (2008) 50:6 Environment: Science \& Pol'y for Sustainable Devlpt 8. 
decades to millennia." 26 The IPCC also observes that "[h]uman influence on the climate system is clear," 27 adding: "[i]t is extremely likely that human influence has been the dominant cause of the observed warming since the mid-20th century" 28 through the emission of greenhouse gas, including $\mathrm{CO}_{2} \cdot{ }^{29}$ On the other hand, some scientific uncertainty remains, in particular, about the precise reactions of the climate system to anthropogenic greenhouse gas emissions ("feedback mechanisms" and "tipping points") ${ }^{30}$ and the particular local or regional effects of a change in the global climate system. ${ }^{31}$ The scale of future climate change will partly depend on measures adopted at international, domestic, local and individual levels, but "[m]ost aspects of climate change will persist for many centuries even if emissions of $\mathrm{CO}_{2}$ are stopped." 32

Climate change is having an impact on human societies, and this impact will increase as the climate continues to change as a consequence of past and continuing greenhouse gas emissions. The IPCC's Fifth Assessment Report estimates that global average temperature has increased by 0.85 Celsius between 1880 and 2012, ${ }^{33}$ and that, without mitigation policies, these temperatures will increase from 3.7 to 4.8 Celsius over pre-industrial levels by $2100 .{ }^{34}$ Due to the ocean's thermal expansion and the melting of glaciers and ice sheets, the average sea level has risen by an estimated 19 centimetres between 1901 and 2010, with an increasing speed over the last decades. ${ }^{35}$ Existing models estimate that global average sea level will rise by between 26 and 98 centimetres during the 21 st century. ${ }^{36}$ These models are based on the conservative "medium confidence" assumption that the Antarctic ice

26 Lisa Alexander et al., "Summary for Policymakers" in IPCC, Climate Change 2013: The Physical Science Basis (AR5 Working Group I) (C.U.P. 2014) 3 at 4.

27 Ibid., at 15.

28 Ibid., at 17.

29 Ibid., at 13-14.

30 See Thomas Stocker et al., "Technical Summary," in ibid., 33 at 115.

31 See generally Bruce Hewitson et al., "Regional Context" in IPCC, Climate Change 2014: Impacts, Adaptation, and Vulnerability (AR5 Working Group II) vol. 2 (C.U.P. 2014) 1133.

32 Alexander et al., n.27, at 27.

33 Ibid., at 5.

34 Ottmar Edenhofer et al., "Summary for Policymakers" in IPCC, Climate Change 2014: Mitigation of Climate Change (AR5 Working Group III) (C.U.P. 2015) 1 at 8 .

35 Alexander et al., n.27, at 11.

36 Ibid., at 25. 
sheet will not collapse catastrophically within the century but rather progressively over the following centuries. ${ }^{37}$ Dramatic changes in climate and sea levels will continue to take place in the following centuries and millennia until the Earth system can reach a new equilibrium. ${ }^{38}$ Already in the 21 st century, however, these changes will reflect in local temperatures and precipitation patterns, and they will affect the frequency or severity of some extreme weather events. ${ }^{39}$ Climate change poses yet relatively ill-measured risks for human and natural systems, for instance through affecting water resources, food production, biodiversity, and possibly human health. ${ }^{40}$ Physical impacts are likely to be unevenly distributed and they may be exacerbated by social stressors, in particular by poverty. ${ }^{41}$

The impacts of climate change are likely to have a range of consequences on human mobility. In history, natural climatic variations were often accompanied with large displacements of populations. ${ }^{42}$ The Barbarian's invasions of the Roman Empire coincided with a colder period in Eastern Asia and with a milder climate in Europe, leading an early 20th century historian to conclude that "[t]he movements of this times are unquestionably due to climate." 43 Likewise, some studies have associated climatic variations with the Mongols' repeated incursions into China (which led to the construction of the Great Wall), ${ }^{44}$ and even, in the 13th

37 Ibid.

38 See e.g. Anders Levermann et al., "The Multimillennial Sea-Level Commitment of Global Warming" (2013) 110:34 PNAS 13745; Kirsten Zickfeld et al., "Long-Term Climate Change Commitment and Reversibility: An EMIC Intercomparison" (2013) 26 Journal of Climate 5782-809; Michiel Schaeffer, "Long-Term Sea-Level Rise Implied by $1.5^{\circ} \mathrm{C}$ and $2^{\circ} \mathrm{C}$ Warming Levels" (2012) 2 Nature Climate Change 867-70.

39 Simon Allen, "Summary for Policymakers" in IPCC, Managing the Risks of Extreme Events and Disasters to Advance Climate Change Adaptation (A Special Report of Working Groups I and II) (C.U.P. 2012) 3 at 9.

40 Christopher Field et al., "Summary for Policymakers" in IPCC (AR5 WGII), n.32, vol.1, 1 at 4-7.

41 Ibid., at 6.

42 See generally Anthony Penna, The Human Footprint: A Global Environmental History (Wiley, 2010); William Burroughs, Climate Change in Prehistory: The End of the Reign of Chaos (C.U.P. 2005).

43 Huntington, n.8, at 373.

44 Jin-Qi Fang and Guo Liu, "Relationship between Climatic Change and the Nomadic Southward Migrations in Eastern Asia during Historical Times" (1992) 22:2 Climatic Change 151; Anatoly Khazanov, "Characteristics Features of Nomadic Communities in Eurasian Steppes" in Wolfgan Weissleder, ed., The Nomadic Alternative (Mouton, 1978) 120 at 121. 
century, with the expansion of the Mongolian empire of Genghis Khan all the way to Eastern Europe. ${ }^{45}$ During the mid-17th century's "little ice age," a third of the world's population died from famines and epidemics, while many others migrated. ${ }^{46}$ Even the 1815 eruption of Mount Tambora, in Java, had diffuse climatic consequences which have been correlated with diverse social and cultural phenomena in the following years, including changes in migration patterns. ${ }^{47}$ Given these historical precedents, the observation and prediction of changes of a scale "unprecedented over decades to millennia" 48 should be of the highest concern.

Building on past discussions on environmental factors of migration, human mobility was rapidly identified as one of the possible impacts of climate change on human societies. ${ }^{49}$ Within international negotiations, the concept came to the fore, in no small part, as a concern for state security. In particular, it was one of the central themes of the UN Security Council's first discussion on the impact of climate change on peace and security in 2007.50 The concept was further discussed in a 2009 report of the Secretary General on "climate change and its possible security implications." 51 In 2010, the 16th session of the Conference of the Parties (COP) to the UN Framework Convention on Climate Change

45 See Neil Pederson et al., "Pluvials, Droughts, the Mongol Empire, and Modern Mongolia" (2014) 111:12 PNAS 4375; Mara Hvistendahl, "Roots of Empire" (2012) 337:6102 Science 1596.

46 Geoffrey Parker, Global Crisis: War, Climate Change and Catastrophe in the Seventeenth Century (Yale U.P. 2013).

47 See William K. Klingaman, The Year without Summer: 1816 and the Volcano that Darkened the World and Changed History (St. Martin's, 2013), Ch. 10 .

48 Alexander et al., n.27, at 4.

49 The 1994 UN Convention to Combat Desertification in Those Countries Experiencing Serious Drought and/or Desertification, Particularly in Africa has already mentioned "migration caused by environmental factors" as a priority area for further research" (art.17(1)(e)).

50 See Security Council 5663rd meeting on 17 April 2007, S/PV.5663 and S/PV.5663 (Resumption 1). See also Francesco Sindico, "Climate Change: A Security (Council) Issue" (2007) 2007 Carbon and Climate L.Rev. 29; Karen E. McNamara and Chris Gibson, "We Do Not Want to Leave our Land': Pacific Ambassadors at the United Nations Resist the Category of 'Climate Refugees", (2009) 40:3 Geoforum 475.

51 Report of the Secretary General on Climate Change and its Possible Security Implications, A/64/350, 11 September 2009. See also Climate Change and its Possible Security Implications, G.A.Res.63/281, 11 June 2009. 
(UNFCCC) encouraged "measures to enhance understanding, coordination and cooperation with regard to climate change induced displacement, migration and planned relocation, where appropriate, at the national, regional and international levels" 52 within its scheme of enhanced actions on adaptation. In 2012, a decision of the 18th COP on the "loss and damage associated with climate change impacts" acknowledged the need to enhance understanding of "how impacts of climate change are affecting patterns of migration, displacement and human mobility." 53 The same year, Switzerland and Norway convened the "Nansen Initiative" on "disaster-induced cross-border displacement," a series of regional consultations which concluded in 2015. ${ }^{54}$ In 2015, the decision of the Conference of the Parties to the UNFCCC adopting the Paris Agreement initiated a process to "develop recommendations for integrated approaches to avert, minimize and address displacement related to the adverse impacts of climate change." 55

\section{THE CONCEPT OF CLIMATE MIGRATION}

There is a step between asserting that climate change has an impact on migration (as suggested in the previous section) and conceptualizing "climate migration" as a distinct phenomenon which could be the object of specific norms or policies. This section argues that, in general, this step cannot be made: climate migration cannot be addressed in isolation from broader environmental or protection issues. In addition, this section also submits that, even if it was possible, this step should not be made: there is no coherent rationale to address climate migration in isolation from other forms of migration or from other adverse consequences of climate change. However, the political momentum generated by discourses on "climate migration" sheds light on some more structural

52 Decision 1/CP.16, The Cancun Agreements: Outcome of the work of the Ad Hoc Working Group on Long-term Cooperative Action under the Convention (2010) at $14(\mathrm{f})$.

53 Decision 3/CP.18, Approaches to Address Loss and Damage Associated with Climate Change Impacts in Developing Countries that are Particularly Vulnerable to the Adverse Effects of Climate Change to Enhance Adaptive Capacity (2012), para.7(a)(vi).

54 The Nansen Initiative, Fleeing Floods, Earthquakes, Droughts and Rising Sea Levels: 12 Lessons Learned About Protecting People Displaced by Disasters and the Effects of Climate Change (final report, 2015).

55 Decision 1/CP.21, Adoption of the Paris Agreement (2015), para.50. 
tensions in global governance, which have arguably not received sufficient attention otherwise. Despite its numerous analytical deficiencies, the concept of "climate migration" is a strong tool for advocacy - a tool which could be used for the better or for the worst.

\section{A. Understanding the Climate-Migration Nexus}

It is a field that has political currency despite the absence of coherence, and in which a lot is being written without anything definitive being said. As a consequence, while often well meaning, the discussion remains largely meaningless. ${ }^{56}$

The impossibility of identifying individual "climate migrants" is a source of great anxiety among scholars in the field. If one cannot distinguish "climate migrants" in the first place, how could a protection mechanism be implemented? Empirical studies and conceptual reflections indicate that climate change may impact any migration scenario, and it does not result in any genuinely new migration scenarios. These considerations suggest that "climate migration" cannot be approached as a concrete phenomenon, ${ }^{57}$ but only as an abstract causal relation - a nexus between two different fields of global governance and perhaps an occasion for two epistemological communities to interact.

\section{Indistinct migrants}

A first difficulty with the concept of climate migration is that it does not relate to particular individuals. It is highly problematic to attribute an individual migrant to climate change in isolation from multiple other factors, or to determine convincingly that an individual would not have migrated absent excessive historical greenhouse gas emissions, or that climate change was otherwise an important causal factor. Even though climate change has a diffuse impact on human mobility, there simply are no distinguishable "climate migrants," as individual migrants who could be distinctively attributed to climate change.

To begin with, there are difficulties in attributing any particular physical phenomenon to climate change. Attribution is most problematic with regard to extreme weather events, even those whose frequency or

56 Calum Nicholson, "Climate Change and the Politics of Causal Reasoning: The Case of Climate Change and Migration" (2014) 180:2 Geographical J. 151 at 152 .

57 Calum Nicholson, Book review (Climate Change, Forced Migration, and International Law, by Jane McAdam) (2013) 26:2 J. Refugee Stud. 311 at 312. 
intensity may be altered by climate change. The concept of climate change relates to probabilities or frequencies, not to the kind of all-ornothing causal relation that lawyers are trained to seek and identify. Concretely, there are and will be more hot days or more tornadoes in certain regions of the world, but no single hot day or tornado can be attributed to climate change. Likewise, the increase of monsoon precipitations in Southeast Asia ${ }^{58}$ results in an increased probability of severe floods in the region, but this does not mean that the specific floods that inundated Pakistan and China in 2010 can be directly attributed to climate change. Recent scientific works are developing tools for a "probabilistic attribution" of extreme weather events to climate change, which would essentially enable an assessment of the increased likelihood of a particular event that can be attributed to anthropogenic climate change. ${ }^{59}$ Yet, probabilistic attribution will not help in identifying individuals who are migrating because of climate change - they are more likely to facilitate assessments or predictions of general trends of human mobility.

Climate change also results in slow-onset environmental changes such as desertification and sea level rise. These changes, however, only occur over very long periods of time, so slowly that their "signal" is often difficult to disentangle from other changes generated by local environmental degradation, natural regional climatic variability, and political, social, economic and demographic transformations. Sea level rise is a major threat to low-lying territories over the long term, but it is imperceptible on the short term: the IPCC's Fifth Assessment Report estimated that the mean rate of sea level rise over the last two decades was around $3.2 \mathrm{~mm}$ per year; the total sea level rise observed since 1901 cumulated to around $19 \mathrm{~cm} .{ }^{60}$ Other slow dynamics, including tectonic processes, may occur at a faster pace; ${ }^{61}$ demographic growth and local

58 Jens Hesselbjerg Christensen et al., "Climate Phenomena and their Relevance for Future Regional Climate Change" in IPCC (AR5 WGI), n.27, 1217 at 1234 .

59 See Dáithí Stone and Myles Allen, "The End-to-End Attribution Problem: From Emissions to Impacts" (2005) 71:3 Climatic Change 303; Pardeep Pall et al., "Anthropogenic Greenhouse Gas Contribution to Flood Risk in England and Wales in Autumn 2000" (2011) 470:7334 Nature 382; Christian Huggel et al., "Loss and Damage Attribution" (2013) 3:8 Nature Climate Change 694.

60 Alexander et al., n.27, at 11.

61 See Stocker et al., n.31, at 100-101; Valérie Ballu et al., "Comparing the Role of Absolute Sea-Level Rise and Vertical Tectonic Motions in Coastal Flooding, Torres Islands (Vanuatu)" (2011) 108:32 PNAS 13019; Arthur Webb and Paul Kench, “The Dynamic Response of Reef Islands to Sea-Level Rise: 
environmental degradation may also affect the vulnerability of populations living in fragile territories. ${ }^{62}$ Thus, what communities experience on a daily basis - floods caused by a storm, a cyclone, or even exceptionally high tides, or erosion often exacerbated by particular use of the territory 63 - is difficult to relate directly to sea level rise. As two specialists note, "for the great majority of island residents, climate change will exacerbate environmental factors that have been influencing migration decision making for decades."'64

Likewise, desertification can be exacerbated by anthropogenic climate change as well as regional natural climatic variability, but local factors are often more clearly perceptible. Case studies show that the impact of warming temperature and changing precipitation patterns in the arid steppes of central Asia is exacerbated by political choices, in particular conflicting development priorities, severe overgrazing of pasturelands, ${ }^{65}$ and unsustainable irrigation practices around the Aral Sea. In low-lying coastal regions of South and Southeast Asia, shrimp farming has been shown to aggravate climate change-related salt-water intrusion. ${ }^{66}$ In each of these examples, adverse effects of climate change are certainly part of the story, but the story itself has much more to do with social, political or geophysical dynamics.

Whether attributable to climate change or not, weather events and slow-onset changes do not mechanically cause migration. As Mike Hulme observes, environmental hazards "are always mediated through complex political, social and economic structures." 67 A "natural disaster,"

Evidence from Multi-Decadal Analysis of Island Change in the Central Pacific" (2010) 72:3 Glob. \& Planetary Change 234.

62 Sandra McCubbin, Barry Smit and Tristan Pearce, "Where Does Climate Fit? Vulnerability to Climate Change in the Context of Multiple Stressors in Funafuti, Tuvalu" (2015) 30 Glob. Envtl Change 43.

63 See e.g. Oli Brown, Migration and Climate Change (IOM, 2008) at 26.

64 John Campbell and Richard Bedford, "Migration and Climate Change in Oceania" in Etienne Piguet and Frank Laczko, eds, People on the Move in a Changing Climate, 2 (Springer, 2014) 177 at 177 (emphasis added).

65 See Benoît Mayer, "Climate Migration and the Politics of Causal Attribution: A Case Study in Mongolia" (2016) 5 Migrat \& Dvlpt 234.

66 See e.g. Brojo Gopal Paul and Christian Reinhard Vogl, "Impacts of Shrimp Farming in Bangladesh: Challenges and Alternatives" (2011) 54:3 Ocean \& Coastal Management 201; Tran Thanh Be, Le Canh Dung and Donna Brennan, "Environmental Costs of Shrimp Culture in the Rice-growing Regions of the Mekong Delta" (1999) 3:1 Aquaculture Econ. \& Management 31.

67 Mike Hulme, "Attributing Weather Extremes to 'Climate Change': A Review” (2014) 38:4 Prog Physical Geogr 499, at 509. 
that is to say a disaster triggered by a natural event, can only occur when a population is exposed (i.e. physically present in the concerned area) and vulnerable (i.e. susceptible of being adversely affected by the natural event). ${ }^{68}$ Development, socio-political structures and demography largely affect the ability of a society to prepare and respond to potentially challenging environmental conditions. These factors result in somewhat paradoxical situations, whereby the Netherlands, which has invested in an expansive dyke system, is less likely to undergo severe floods than Bangladesh, while Qatar, which runs seawater desalination a great scale, faces less risk of drought than Kiribati, a small island in the Pacific. In turn, when adversely affected by climate or weather events, populations do not always migrate. Migration studies have constantly shown, for instance, that the poorer fringes of a society are less likely to migrate, for lack of means, even though they are often the most severely affected by climate or weather events. ${ }^{69}$

The difficulty of attributing weather events or slow-onset changes to anthropogenic climate change, and then attributing migration to these events, is a conceptual rather than definitional issue. If the difficulty was just one of defining "climate migrants," it could surely be overcome by some agreement on methodology, perhaps some threshold of causation, as in the case of a definition of conventional refugees. ${ }^{70}$ Yet, the difficulty lies more deeply in the fact that, because of the long and highly consequential causal chain between climate change and migration, individual migrants can generally not be attributed to climate change.

This conceptual difficulty has naturally hindered all attempts to estimate the numbers of "climate migrants," let alone developing meaningful predictions. ${ }^{71}$ In what stands to date as the most meaningful global estimate on a related subject, the Internal Displacement Monitoring Centre (IDMC) has been monitoring displacements induced by suddenonset natural disasters each year since 2008. On a five-year average, the

68 See for instance ASEAN Agreement on Disaster Management and Emergency Response, 26 July 2005, art.1(3); Tampere Convention on the Provision of Telecommunication Resources for Disaster Mitigation and Relief Operations, 18 June 1998, art.1(6).

69 See Foresight, n.22.

70 Thus, some literature has developed to try to define "climate migrants." See e.g. Olivia Dun and François Gemenne, "Defining 'Environmental Migration"” (2008) 31 Forced Migration Rev. 10-11.

71 François Gemenne, "Why the Numbers Don't Add Up: A Review of Estimates and Predictions of People Displaced by Environmental Changes" (2011) 21 Glob. Envt'l Change Supp. 1 S41. 
IDMC estimates that sudden-onset natural disasters (including geophysical ones such as tsunamis, earthquakes, or volcanic eruptions) displaced about 29 million persons each year in average. Weather-related sudden-onset disasters accounted for the most of these displacements: in average, about 23 million per year. More than 80 per cent of those displaced were accordingly in Asia. ${ }^{72}$ However, this estimate does not evaluate the migratory impact of slow-onset environmental changes, and it does not attempt to attribute any displacement to climate change. Going further, analyses based on probabilistic attribution of events could in principle be developed to evaluate the statistical impact of climate change on migration. ${ }^{73}$ These abstract numbers would reflect the weight of climate change as an indirect factor of migration and they may have great political significance. Yet, such figures would not correspond to a distinctive population of "climate migrants" who could possibly be identified and dealt with differently, but only to the attribution of a statistical change in overall migrant populations.

\section{Miscellaneous forms of mobility}

Although individual "climate migrants" cannot be identified, efforts have been made to try to identify relevant scenarios of human mobility that could be related to climate change. Thus, Walter Kälin suggested distinguishing five scenarios of "climate change-induced displacement" on the basis of the situation that most directly pushes individuals to move:

1. Sudden-onset disasters causing mostly internal, but sometimes cross-border displacements. Flooding or cyclones, for instance, can induce populations to move away from affected territories, generally on a temporary basis.

2. Slow-onset environmental degradation deteriorating the conditions of life and inducing both internal and international economic migration. Sea-level rise and the consequences of increasing average temperatures (drought, desertification, land degradation) can generally be conceived as a migration "push," in particular through affecting economic conditions at the place of origin.

72 Michelle Yonetani, Global Estimates 2014: People Displaced by Disasters (IDMC, 2014).

73 The many methodological tools available to social scientists are discussed in Etienne Piguet, "Linking Climate Change, Environmental Degradation, and Migration: A Methodological Overview" (2010) 1:4 Wiley Interdisciplinary Rev. Climate Change 517. 
3. The specific case of "sinking" small island states, causing international economic migration and, possibly, evacuation. Absent innovative measures of adaptation, low-lying islands or archipelagos such as the Maldives, Kiribati and Tuvalu will become unable to accommodate their population, in the long term, as a consequence of sea-level rise.

4. The designation of certain areas as high-risk zones too dangerous for human habitation, leading to the evacuation of the resident population. Such measures are often taken, in particular, in flood plains or in the vicinity of rivers.

5. Unrest, violence or conflicts exacerbated by an increased competition for natural resources leading to flows of refugees or internally displaced persons. Resource-scarce regions are most likely to be affected, when tensions are already in place in respect of access to limited natural resources. ${ }^{74}$

Each of these situations can lead to different forms of displacements, for instance to internal or international mobility, depending on specific circumstances. These five scenarios are examples, arguably archetypes, of climate migration, but they do not constitute an exhaustive typology of scenarios of human mobility that are affected by climate change. Climate change may have an impact well beyond these five archetypes. There are other scenarios of migration affected by climate change, or by responses to climate change, including:

1. Economic migration triggered mainly by "pull" factors in places where new economic opportunities arise as a result of positive impacts of climate change. For instance, the lengthening of the growing season in some Northern regions where fresh water is abundantly available (parts of Canada, the United States and Russia) may allow a development of the agricultural sector, which often employs seasonal foreign labour. ${ }^{75}$

74 Walter Kälin, “Conceptualizing Climate-Induced Displacement" in Jane McAdam, ed., Climate Change and Displacement: Multidisciplinary Perspectives (Hart, 2010) 81 at 85-6.

75 See e.g. Anabella Rosemberg, "Building a Just Transition: The Linkages between Climate Change and Employment" (2010) 2:2 Int'l J. Labour Res. 125 at 130; Agriculture and Agri-Food Canada, Assessment of Climate Change Impacts on Agricultural Land-Use Suitability: Spring Seeded Small Grains on the Prairies (2008); Olivier Deschenes and Michael Greenstone, "The Economic 
2. Programs of development-induced displacement and resettlement associated with projects justified, in whole or in part, by climate change mitigation or adaptation. This includes Kälin's fourth scenario (designation of certain areas as high-risk zones) but extends beyond. Additional water reservoirs can be built to reduce risks of drought, or additional dykes to protect populations against floods. ${ }^{76}$ Hydroelectric dams, which have often been associated with large resettlement programs, have been presented as a source of clean energy as well as a way to reduce risks of floods, and some hydroelectric projects have been funded by climate finance. ${ }^{77}$

2. The diffuse incidence of economic incentives induced by action on climate change mitigation. The development of the biofuel industry or reforestation projects affects the way lands are being used, hence also patterns of human settlement. In developing countries with weak institutions, such orientations may result in land-grabbing and in the expulsion of marginalized communities, including Indigenous peoples. ${ }^{78}$ Likewise, mitigation policies have an impact on the vitality of specific economic sectors, including industrial ones, and hence also on employment, ${ }^{79}$ which is both a "push" and "pull" factor of migration. ${ }^{80}$ Places specializing in coal mining, for instance, may one day be affected by more stringent mitigation policies. On the other hand, the Kyoto Protocol was repeatedly

Impacts of Climate Change: Evidence from Agricultural Output and Random Fluctuations in Weather" (2007) Am. Econ. Rev. 354.

76 See Elena Correa, Preventive Resettlement of Populations at Risk of Disaster: Experiences from Latin America (World Bank, 2011); Elena Correa, Fernando Ramírez and Haris Sanahuja, Populations at Risk of Disaster: A Resettlement Guide (World Bank, 2011); Christopher McDowell, "ClimateChange Adaptation and Mitigation: Implications for Land Acquisition and Population Relocation" (2013) 31:6 Dvlpt Pol'y Rev. 677.

77 For instance, about the Barro Blanco hydroelectric dam, see: Movimiento 10 de Abril et al., Imminent Forced Evictions of Indigenous Ngöbe Families due to Barro Blanco Dam in Panama (2014).

78 See Michael Winter and Matt Lobley, What Is Land For? The Food, Fuel and Climate Change Debate (Earthscan, 2009) at 270 (referring to a prediction of 60 million "biofuel refugees").

79 See Dan Cunniah, "Preface" (2010) 2:2 Int'1 J. Labour Res. 121 at 122, noting that, "if the transition to a greener economy generates employment, it will also entail job losses for some."

80 See e.g. Miguel Esteban et al., "The Greening of the Offshore Energy Sector in the North Sea" (2010) 2:2 Int'1 J. Labour Res. 245; Jerry van den Berge, "Employment Opportunities from Climate Change Mitigation Policies in the Netherlands" (2010) 2:2 Int'l J. Labour Res. 211. 
accused of favouring a carbon leakage from developed countries bound by specific emissions reduction obligations, to developing countries - thus reinforcing the economic development of exportoriented industries in China's coastal provinces, which attract hundreds of millions of internal migrant workers. ${ }^{81}$ Lastly, mitigation objectives could lead to policies that affect patterns of settlement, possibly by promoting demographic concentration in urban centres rather than urban sprawl. ${ }^{82}$

4. Migration exacerbated by climate change may, in turn, push other individuals to move in a domino effect. In particular, countries subjected to more frequent natural disasters, resulting in an acceleration of already rampant urbanization, a degradation of the living conditions may push an urbanite elite with the means to do so to migrate abroad. Thus, through seven focus groups on new migrants to Canada coming from the Horn of Africa and francophone sub-Saharan Africa, Luisa Veronis and Robert McLeman have shown that environmental factors can "act ... as second- or thirdorder contributors to longer, complex chains of interactions that for some groups or individuals can lead to long-distance international migration." 83 Rapid urbanization could, in other socio-political contexts, be an opportunity for development; development, however, could also create a larger urban elite with the sufficient means to envisage international migration.

These additional scenarios highlight some issues with determining causation. The physical effects of climate change produce series of social effects which, like the concentric circles that an impact produces on a water surface, extend ad infinitum and at absurdum in time and space. It is hardly an exaggeration to state that the impacts of climate change can have virtually any consequence on any form of migration, and that the

81 See Ye Qi, Huimin Li and Tong Wu, "Interpreting China's Carbon Flows" (2013) 110:28 PNAS 11221; Aijun Li et al., "How Large Are the Impacts of Carbon-Motivated Border Tax Adjustments on China and How to Mitigate Them?" (2013) 63 Energy Pol'y 927.

82 See e.g. István László Bart, "Urban Sprawl and Climate Change: A Statistical Exploration of Cause and Effect, with Policy Options for the EU" (2010) 27:2 Land Use Pol'y 283; Harriet Bulkeley, Cities and Climate Change (Routledge, 2013).

83 Luisa Veronis and Robert McLeman, "Environmental Influences on African Migration to Canada: Focus Group Findings from Ottawa-Gatineau" (2014) Popul \& Envt 1 at 234. 
decisions to migrate or not to migrate that each of us repeatedly makes in the course of our life could always be, in some ways, related to climate change.

Moreover, even the scenarios that appear as most directly related to climate change display a great diversity, for instance regarding the length of the displacement (permanent, temporary, repetitive), the degree of coercion and that of preparedness or organization, the gender and age dimensions (and whether migrants move individually or with their family), and the distance (including whether or not international borders are crossed). ${ }^{84}$ These factors are central to any legal response, determining both the status of migrants (e.g. internal or international migrant) and their protection needs. Yet, these factors largely depend on the settings in which weather events or slow-onset changes occur and on the way response measures are conceived and implemented. For instance, a drought often increases migration flows, ${ }^{85}$ but it may also deprive communities of the resources necessary to undertake circular migration. ${ }^{86}$ Likewise, the readiness of a population to leave in the face of a disaster and then to return home quickly may be influenced by fears of robbery or land-grabbing or by the integration of the displaced population at the place of destination. ${ }^{87}$ Even in relatively obvious cases of mass displacements directly related to a natural disaster, environmental events do not "create" migration and vulnerability in a vacuum - and a lot is possibly lost when singling out one relevant causal dimension and excluding the many others.

The literature on climate change and migration has often focused on few of the many possible relevant scenarios. Some of this selection is apparently based on a reasonable distinction between scenarios more or less likely to involve human suffering. ${ }^{88}$ In particular, more attention has justly been paid to forced rather than voluntary migration. Yet, other

84 See e.g. François Gemenne, Environmental Changes and Migration Flows: Normative Frameworks and Policy Responses ( $\mathrm{PhD}$ thesis, Sciences $\mathrm{Po} /$ Univ. Liège, 2009) at 173.

85 See e.g. Warner, Afifi and Henry, n.22.

86 Oli Brown, Eating the Dry Season: Labour Mobility as a Coping Strategy for Climate Change (IISD Commentary, 2007).

87 See François Gemenne, "What's in a Name: Social Vulnerabilities and the Refugee Controversy in the Wake of Hurricane Katrina" in Tamer Afifi and Jill Jäger, eds, Environment, Forced Migration and Social Vulnerability (Springer, 2010) 29, reflecting in particular on the low return rate among the persons displaced in conjunction with hurricane Katrina.

88 See for instance Alana Shaw, Book review (Climate Refugees, by Collectif Argos, Jean Jouzel and Hubert Reeves) (2014) 29:2 Refuge 101 at 101. 
selections are rather guided by representations of the Other, or mere ideologies. That small islands have become the centre of attention in much of the public representation of "climate refugees" has more to do with the collective representations of these islands as pristine, innocent and fragile than with the numbers of individuals concerned or the relative urgency of their protection needs. By contrast, the populations displaced by development, adaptation, or mitigation projects have not generally received the same degree of empathy, as if well-meaning action on climate mitigation or adaptation could not harm.

More attention has also been paid to hypotheses where climate change increases migration flows, but the greater vulnerability of populations who are not able to adapt through migrating for want of material, political or social resources ("climate sedentariness") has by and large been neglected. ${ }^{89}$ This focus on the inducement to migrate rather than the inducement not to migrate reflects a misleading assumption that sedentariness is the norm and migration the anomaly. Of late, a new discourse has emphasized the possibility of opportunistic temporary labour migration programs that could benefit the sending community, the receiving community and the migrants themselves - but where little focus is put on the rights of the migrants, considered exclusively as economic agents. ${ }^{90}$

\section{Indistinct migration scenarios}

Climate change may affect virtually any migration scenario, but it does not create (or, at the very least, has not yet created) any unfamiliar scenarios - any new forms of human distress, for instance, that could create distinct governance needs. The individuals displaced by weather events (scenario 1) or slow-onset changes (scenario 2) need protection, whether these events could somehow be associated with climate change or not. As Walter Kälin notes, "it is conceptually sounder to look at sudden-onset disasters as a cause of displacement, and not to limit the focus to those triggered by global warming." ${ }^{91}$ Similarly, slow-onset environmental degradation generally exacerbates trends of urbanization,

89 See Foresight, n.22, at 9.

90 See e.g. Jon Barnett and Michael Webber, "Migration as Adaptation: Opportunities and Limits" in McAdam, n.75, 41; Richard Black et al., "Climate Change: Migration as Adaptation" (2011) 478:7370 Nature 447.

91 Kälin, n.75, at 85. 
creating in particular needs for infrastructure development, thus exacerbating broader trends of internal mobility. ${ }^{92}$ Regulation of human settlement in dangerous areas has long been implemented, for instance against exposure to industrial or natural disasters; similar policies will likely be used in response to changing natural hazards as a consequence of climate change (scenario 4). While climate change may exacerbate tensions between communities through increased competition for certain natural resources, this will not lead to patterns of migration qualitatively different from existing violence-induced forced migration (scenario 5).

Likewise, economic factors of migration related to positive impacts of climate change (scenario 6) do not differ from economic incentives triggered by existing differences in economic opportunities within and across states. Development-induced displacement and resettlement do not differ in any meaningful ways depending on the nature of the development project at stake: a dam involves similar resettlement schemes whether it is justified as a way of producing cheap electricity or clean energy, or even as water management (scenario 7). The economic reconversion that a turn to a "green economy" may cause (scenario 8) can be compared, for instance, with massive internal migrations in Southeast Asia in the 1960s, following the global decline in demand for natural rubber. ${ }^{93}$ Lastly, domino migration caused by rampant urbanization occurs whether or not urbanization is accelerated by climate change (scenario 9). All these scenarios may be exacerbated by climate change, but they are not new, and they do not unfold in any new way.

For these reasons, the specific case of the evacuation of "sinking" island states (scenario 3) is the strongest candidate for a scenario that could plausibly be considered a "new" one, specific to climate change although I will argue that it should probably not. Small, low-lying island states such as Kiribati, the Maldives or Tuvalu are heavily affected by sea level rise, more extreme weather events, and droughts, in conjunction with other, local factors. Absent innovative responses, these territories will become uninhabitable, in particular for lack of drinking water as seawater intrudes in natural fresh water reserves. On a longer term,

92 See e.g. Md. Shahidul Haque, "Migration Trends and Patterns in South Asia and Management Approaches and Initiatives" (2005) 20:3 Asia Pacific Population J. 39; Shahadat Hossain, "Rapid Urban Growth and Poverty in Dhaka City" (2008) 5:1 Bangladesh e-Journal of Sociology.

93 Alan Burtham Simmons, Sergio Díaz-Briquets and Aprodicio Laquian, Social Change and Internal Migration: A Review of Research Findings from Africa, Asia and Latin America (International Development Research Centre, Migration Review Task Force, 1977) at 45-6. 
erosion and loss of territory threaten the very existence of these isolated territories, which are already among the most densely populated in the world and the most fragile environments. Even before the territory disappears totally, it may become impossible for individuals to live on these isolated islands without freshwater resources, or life there might become unsafe due to increasing exposure to extreme storms.

The resettlement of the whole population of particular islands, in itself, is not a new scenario of migration. The entire populations of certain islands were for instance resettled to allow for nuclear testing (Bikini), ${ }^{94}$ for the development of a military base (Diego Garcia), ${ }^{95}$ or for phosphate mining (Banaba, with plans being also made, at a time, for the population of Nauru). ${ }^{96}$ There are also precedents of island evacuations triggered by environmental issues unrelated to anthropogenic climate change: drought (Canton Island and Phoenix islands, Kiribati, in 1963), flooding (Meridean Islands, United States, in the 1900s), sand storm (Shetland Islands Brew settlement, Scotland, 1690-1715), ${ }^{97}$ or local environmental degradation (Vaitupu island, Tuvalu, 1946). ${ }^{98}$

94 See e.g. Robert Kiste, "Identity and Relocation: The Bikini Case" (1985) 26:1 Pacific Viewpoint 116; Jack Niedenthal, "A History of the People of Bikini following Nuclear Weapons Testing in the Marshall Islands, with Recollections and Views of Elders of Bikini Atoll" (1997) 73 Health Physics 28; International Commission to Investigate the Health and Environmental Effects of Nuclear Weapons Production \& Institute for Energy and Environmental Research, Radioactive Heaven and Earth: The Health and Environmental Effects of Nuclear Weapons Testing in, on, and above the Earth (Zed Books, 1991).

95 See e.g. David Vine, Island of Shame: The Secret History of the US Military Base on Diego Garcia (Princeton U.P. 2011); Peter Sand, "Diego Garcia: British-American Legal Black Hole in the Indian Ocean?" (2009) 21 J. Envt'1 L. 113; David Vine, "War and Forced Migration in the Indian Ocean: The US Military Base at Diego Garcia” (2004) 42:3 Int'l Migrat. 111.

96 Ronald Wright, On Fiji Islands (Viking, 1986); Gil Marvel Tabucanon, "The Banaban Resettlement: Implications for Pacific Environmental Migration" (2012) 35:3 Pacific Stud. 343. On early plans for an evacuation of Nauru, see Gil Marvel Tabucanon and Brian Opeskin, "The Resettlement of Nauruans in Australia: An Early Case of Failed Environmental Migration” (2011) 46:3 J. Pacific History 337.

97 Robert McLeman, "Settlement Abandonment in the Context of Global Environmental Change" (2011) 21 Glob. Envtl Change S108 (online supplementary data).

98 R. Bedford and C. Bedford, "International Migration and Climate Change: A Post-Copenhagen Perspective on Options for Kiribati and Tuvalu", in B. Burson, ed., Climate Change and Migration: South Pacific Perspectives (Wellington: New Zealand Institute of Policy Studies, 2010) 89-134. 
Therefore, the novelty of the island evacuation scenario would not be the evacuation of an island, but that of a state. There is no equivalent of the physical "disappearance" of a state in modern history. While many states have ceased to exist, this has always been through absorption, merger, dissolution or annexation - scenarios through which dispositions are in principle adopted, among others, for the nationality of the population. ${ }^{99}$ In the hypothesis of a state's "disappearance," it might be that no succession of obligations is established with another state, with regard in particular to the obligation of protecting the human rights of the population concerned - although this does not need to be the case. An agreement on state succession could for instance be reached before the "disappearance" of the concerned state.

International law scholars have devoted considerable attention to the "fascinating legal issues"100 that "sinking" island states raise, for instance about whether the state would persist once permanently in the absence of some of the elements necessary to its recognition, ${ }^{101}$ about the applicability of the Convention relating the Status of Stateless Persons to the resettled population, or more importantly given the limited scope of protection offered to stateless persons, about the extraterritorial human rights obligations of other states before and after resettlement. ${ }^{102}$ These questions fascinate because they push international lawyers to the limits of their discipline, revealing the unsurmountable contradiction between the obligation of judges to adjudicate on the basis of the law and the indeterminacy of the law. Rather than adjudication, however, the fate of "sinking" island states and their populations is more likely to be decided through diplomatic means. In the process of diplomatic negotiations leading to such decisions, until a norm emerges, more convincing

99 See James Crawford, The Creation of States in International Law (O.U.P. 2007), Ch. 17.

100 Jane McAdam, Climate Change, Forced Migration, and International Law (O.U.P. 2012) at 119.

101 See Montevideo Convention on the Rights and Duties of States, 26 December 1933, 165 LNTS 19, art.1; Crawford, ibid., Ch. 2.

102 See e.g. Michael Gerrard, ed., Threatened Island Nations: Legal Implications of Rising Seas and a Changing Climate (C.U.P. 2013); Lilian Yamamoto and Miguel Esteban, Atoll Island States and International Law: Climate Change Displacement and Sovereignty (Springer, 2014); Susin Park, Climate Change and the Risk of Statelessness: The Situation of Low-Lying Island States (UNHCR, 2011); Tiffany Duong, "When Islands Drown: The Plight of 'Climate Refugees' and Recourse to International Human Rights Law" (2010) 31 U. Pa. J. Int'l L. 1239; Derek Wong, "Sovereignty Sunk? The Position of 'Sinking States' at International Law” (2013) 14:2 Melbourne J. Int'1 L. 346. 
arguments are likely to be based on ethical or interests-centred arguments rather than legal theories.

The disappearance of some of the concerned islands in the coming decades appears inevitable, but the disappearance of the states is not. An artificial inhabitable territory could be maintained, for instance through floating installations ${ }^{103}$ or through the acquisition of new territories elsewhere. The continuity of the state could (although not automatically) guarantee a continued protection to the populations concerned. Such possibilities would involve some displacements of populations within a state, hence in no essential way dissimilar to other instances of island resettlements. In other words, the scenario of a disappearance of "sinking" island states, leaving behind stateless populations seeking asylum, is not inevitable.

Moreover, the hypothetical scenario of landless islanders seeking asylum overseas could also happen for reasons unrelated to climate change. It is possible to conceive that an island state may disappear or become uninhabitable permanently or for a very long period of time, uniquely because of natural subsidence, local environmental degradation, or even an industrial disaster. As noted, other factors are indeed at play in at least some of the "sinking" island states. That states may conceivably "disappear" for reasons unrelated to climate change suggests that responses to such scenarios should perhaps not be framed in terms specific to climate change, but in general and abstract terms. Climate change makes the scenario of a state's disappearance much more likely to occur, but the scenario itself is not inherently limited to climate change.

Lastly, with regard to the protection of the migrants (as opposed to the intriguing legal issues about statehood), the hypothesis of a state unable to protect its own population is not a new issue. Similar circumstances, triggered for instance by conflicts, economic crises, and environmental changes, or a combination, have often been discussed, for instance in the case of "state failure"104 or situations triggering "survival migration."105 A difference might be that there would be no opportunity to ever come back to a sinking island, whereas a conflict can end, and a failing state

103 See Yamamoto and Esteban, ibid., at 131-69, discussing conceivable in situ adaptation scenarios such as coastal structures, houses on piles, elevation of an entire island, floating island and reconstruction of an island after it has disappeared.

104 Robert Rotberg, "The New Nature of Nation-State Failure" (2002) 25 The Washington Quarterly 83.

105 Alexander Betts, Survival Migration: Failed Governance and the Crisis of Displacement (Cornell U.P. 2013). 
can recover. But, it is uncertain whether this difference is of great significance. For the hosting states and for many of the refugees themselves, return is often a very unlikely prospect.

By contrast to countries like Bangladesh and Nigeria, the small size of the population concerned by "sinking" small island states and the great amount of public attention gives reasonable hopes that innovative forms of in situ adaptation could be deployed or that, otherwise, international resettlement could be organized smoothly, through ad hoc political arrangements by neighbouring or further-off states either accepting to succeed to the human rights obligations of these "sinking" states toward their populations, or ceding a territory to relocate the state as such. ${ }^{106}$ Such ad hoc political agreements could solve the issue of "sinking" island states, but they would not solve the much greater issues flagged by discourses on the climate-migration nexus more generally.

\section{B. The Illusive Rationale}

Much is lost, analytically, by seeking to attribute migration to climate change while neglecting all other relevant circumstances - but this also has consequences in spheres of governance because the omission of concurrent causes reduces the number of conceivable responses. Rather than specific adaptation projects, more general development policies could for instance respond more directly and efficiently to many of the migration scenarios discussed above. Because neither migrants nor specific migration scenarios can be entirely attributed to climate change, climate migration appears as a particularly abstract concept reflecting an indirect and generally impalpable causal link, rather than a specific phenomenon capable of being addressed through specific laws and policies.

Going further, it is worth taking a moment of reflection to question whether specific policies on climate migration would even be desirable. For this purpose, we need to set aside the difficulties raised before and to consider, counterfactually, that specific policies could possibly be devised to address something called "climate migration," or to protect a category of "climate migrants." We also need to elude, for a moment, any consideration of political feasibility. If such norms or policies were possible, would they be desirable?

106 Thus, Kiribati purchased land from Fiji in April 2012. See Campbell and Bedford, n.65 at 180 . 
Many existing governance proposals, suggesting for instance a protection of "climate migrants," do a relatively poor job at providing a coherent ethical argument. ${ }^{107}$ Some hints are obvious. First, "climate migrants" (depicted as particularly vulnerable individuals) need protection. Secondly, those states or communities that have been disproportionately contributing to global greenhouse gas emissions may hold specific moral obligations towards those individuals or communities most affected by climate change. Yet, a systematic development of either of these arguments fails to justify discourses that present "climate migration" as a distinct moral concern for global governance, rather than migration, on the one hand, or climate change, on the other. It is a central theme of this book that there is no coherent rationale to justify specific international responses to "climate migration," as opposed to larger reforms applying general principles such as international solidarity or responsibility to more consistent subject matters.

On the one hand, considerations for international solidarity could suggest a duty to help those in need, thus pleading in particular for international protection and assistance toward vulnerable "climate migrants." In its strongest form, this rationale elaborates on theories of global justice such as developed, for instance, by Charles Beitz or Thomas Pogge. ${ }^{108}$ Grounds for "softer" arguments can however be found in virtually any philosophical school, for instance in John Rawls's admission of a "duty to assist other peoples living under unfavourable conditions," 109 and in multiple religious doctrines. However, the international solidarity rationale does not justify responses that would be specific to "climate migration." As shown above, the impacts of climate change will not generally create any new and distinct forms of vulnerability or any new type of needs that would, by nature, be specific to climate change: they will rather exacerbate existing scenarios of human mobility. In other words, the vulnerability of "climate migrants" (whomever this refers to) is not peculiar to them. From an international solidarity perspective, climate migration is essentially just more of the same old issues.

107 Few moral philosophers have been interested in the debate. For a rare exception, see Peter Penz, "International Ethical Responsibilities to 'Climate Change Refugees"” in McAdam, n.75, 151.

108 Charles Beitz, "Justice and International Relations" (1975) 4 Phil. \& Pub. Aff. 360; Thomas Pogge, World Poverty and Human Rights: Cosmopolitan Responsibilities and Reforms (Blackwell, 2002).

109 John Rawls, The Law of Peoples (Harv. U.P. 1999) at 37. 
Thus, an oft-heard argument compares refugees (the international migrants who are protected under the international refugee regime) with a putative category of "climate refugees," and suggests that the protection of the former be extended to the latter. ${ }^{110}$ It is noteworthy that similar arguments had previously been developed for an extension of the 1951 Convention relating to the Status of Refugees, to "economic refugees"111 or "environmental refugees." 112 Although these analogies reveal deep contradictions in today's global governance, it would be arbitrary to limit a protection mechanism to a specific sub-population of migrants distinguished on the ground of the cause of their displacement: if the arguments suggested by such analogies are valid, protection should be extended to all migrants with similar needs. It may for instance be, as Alexander Betts argues, that international institutions ought to provide more systematic protection to the persons fleeing the territory of a state that is unable to ensure their survival. ${ }^{113}$ Alternatively, a group of researchers led by Susan Martin are promoting a conceptual framework on "crisis migration," with a broad definition of "humanitarian crisis," thus including in fact most forms of internal or international forced migration. ${ }^{114}$ Even beyond international and forced migration, similar international solidarity arguments could as well extend to other scenarios of human mobility, for instance to the benefit of persons seeking economic opportunities elsewhere within or without their state of origin,

110 See for instance Biermann and Boas, n.26; David Hodgkinson et al., "The Hour When the Ship Comes In: A Convention for Persons Displaced by Climate Change" (2010) 36 Monash U.L.Rev. 69; Bonnie Docherty and Tyler Giannini, "Confronting a Rising Tide: A Proposal for a Convention on Climate Change Refugees" (2009) 33 Harv. Envtl L.Rev. 349, and, more recently, François Gemenne, "One Good Reason to Speak of 'Climate Refugees"” (2015) 49 Forced Migration Review 70.

111 See e.g. Francis Gabor and John Rosenquest, "The Unsettled Status of Economic Refugees from the American and International Legal Perspectives: A Proposal for Recognition under Existing International Law" (2006) 41 Texas Int'l L.J. 275; Elizabeth Harris, "Economic Refugees: Unprotected in the United States by Virtue of an Inaccurate Label" (1993) 9 Am. U.J. Int'1 L. \& Pol'y 269; Laura Kwiatkowski, "Economic Refugees: Do They Have a Place inside the Golden Door" (1984) 3 Can.-Am.L.J. 189.

112 See e.g. CIDCE, "Draft Convention on the International Status of Environmentally Displaced Persons" in Julien Bétaille and Michel Prieur, eds., Les Catastrophes écologiques et le droit: échecs du droit, appels au droit (Bruylant, 2012).

113 Betts, n.106.

114 Susan Martin, Sanjula Weerasinghe and Abbie Taylor, Humanitarian Crises and Migration: Causes, Consequences and Responses (Routledge, 2014). 
or of populations resettled for diverse objectives of public interests. Even further, a solidarity rationale should also consider non-migrants, in particular those who lack the material, social or political resources necessary to migrate, who are often more vulnerable than migrants themselves - populations "trapped in place" and unable to adapt through migration.

On the other hand, arguments could be made to justify specific responses to climate migration on the ground of a specific causal responsibility of greenhouse gas emitters. However, just like the solidarity rationale is not limited to a cause of migration, the responsibility rationale fails to identify mobility (an effect among others) as a distinct issue within the larger range of adverse social impacts of climate change.

Climate change exacerbates global injustices: the global poor benefit the least from global greenhouse gas emission, but they are the most affected by climate change. Theories of causal responsibility suggest that those most responsible for wrongfully interfering with our climate system owe reparation to those most affected as a consequence of this interference. ${ }^{115}$ Seemingly going in this sense, the principle of common but differentiated responsibilities, adopted through the UN Framework Convention on Climate Change, recognizes that developed states have specific obligations to take the lead in combatting climate change and to facilitate adaptation in those countries most affected by the adverse social impacts of climate change. Thus, migration has most recently been considered as a part of the loss and damage associated with climate change impacts. ${ }^{116}$

If reparation should be made on the ground of climate change responsibilities, however, this should most likely be through compensation between states, as states remain the structuring entities of today's international governance. Alternative possible forms of "reparation" that deal specifically with migrants, such as international resettlement programs or migratory concessions, are not standard forms of reparation. They should arguably be considered as a form of cooperation in mitigating an injury: they should not exhaust the right to reparation. ${ }^{117}$

115 See Henry Shue, "Subsistence Emissions and Luxury Emissions" (1993) 15 Law \& Policy 39; Simon Caney, "Cosmopolitan Justice, Responsibility, and Global Climate Change" (2005) 18:4 Leiden J.I.L. 747; Daniel Farber, "The Case for Climate Compensation: Justice for Climate Change Victims in a Complex World" (2008) Utah L.Rev. 377.

116 Decisions 3/CP.18, n.54, para.7(a)(vi); 1/CP.21, n.56, para.50.

117 This argument is further developed in Ch. 4. 
Responsibility, in other terms, cannot justify further interference in the domestic affairs of the states most affected.118 The states concerned, not any international organization or any third states, should in principle be free to decide how best to adapt to climate change and to respond to migration within their jurisdiction. The injured states should of course be constrained by any applicable international law obligations, in particular international human rights law, for what concerns its duties towards individuals within their jurisdiction - but law is precisely constituted by general and abstract norms, where there should be no arbitrary distinction between similar situations. The norms that should guide an injured state's responses to the social impacts of climate change, including impacts on human mobility, should not differ from the rules that guide other states in similar circumstances. Nothing in the responsibility rationale justifies that injured states be constrained by additional obligations that are not generally imposed on all states dealing with similar migration scenarios.

Thus, neither the principle of international solidarity, nor that of responsibility could justify distinguishing "climate migration" from broader governance issues. Rather, international solidarity suggests international cooperation for the protection of all migrants with similar needs, notwithstanding the different causes to which migration could be attributed. On the other hand, responsibility calls for international cooperation in responding to the adverse social impacts of climate change, notwithstanding the nature of these social impacts. No other coherent ethical reasoning seems able to justify the framing of climate migration as a distinct concern.

\section{Political Momentum}

Observations of a similar nature have led Calum Nicholson to suggest that "potentially more is lost than gained" by focusing on "climate migration."119 In a highly sceptical article, Nicholson lists the symptoms of the "intellectual bewitchment" of many scholars for an inconsistent concept - banal statements, arbitrary claims, ontological contradiction, equivocation, laundering of categories and tautological conclusions - all following from the uncritical assumption that there is a distinct thing behind the concept of "climate migration." 120 Nicholson thus states:

118 It may be an obligation for the injured state to mitigate its damage, but this does not allow interference by the injuring state.

119 Nicholson, n.57, at 151.

120 Ibid., at 152 et seq. 
There is a contradiction that has the following basic structure: there will be an acknowledgement that the "drivers" of migration are always complex and that all migration is conditioned by myriad contingencies and "geo-social-political context". Yet the same authors will often continue to refer to "climate displacement" as if it were an essential and ontologically stable category. In other words, once contextual complexity and the arbitrariness of definitions have been acknowledged, the very same papers will often then go on to discuss "environmental migration" as if those caveats had not been made. ${ }^{121}$

Although this critique is important, I will argue that it is not sufficient to definitely reject the concept of climate migration as a tool for political advocacy or even, perhaps, for governance reform. Social progress rarely comes from strong analytical concepts. Rather, ground-breaking political decisions are often made possible when disagreements are veiled behind vague, unpractical and somewhat arbitrary conceptual frameworks. The difficulty of interpreting statutes or treaties often stems from circumstances where lawmakers concealed substantive disagreements under obscure provisions. A relevant example here can be found in the international refugee regime, which is often used as an analogue by advocates of "climate refugees." A consistent refugee regime would surely be quite different from the actual regime - the definition of a refugee, in particular, would not be limited to specific grounds of persecution ("for reasons of race, religion, nationality, membership of a particular social group or political opinion"), or perhaps not to persecution at all. ${ }^{122}$

Thus, although it is tempting to consider international institutions as the fruit of a rational deliberation, this would be grossly misleading. ${ }^{123}$ International cooperation in any field faces significant political obstacles because it depends on states, whose conduct does not necessarily pursue the "interests" of their own populations, let alone those of humankind in general. To advance international cooperation, political opportunities matter - and climate migration might be a great opportunity for progress in international cooperation.

\footnotetext{
121 Ibid., at 154.

122 I further develop this argument, in particular, in Ch. 3, section II.A.3.

123 A frequent criticism that practitioners make of academic theory is its conception of actors as acting rationally, under predictable patterns. Practitioners tend to insist that foreign policy is "an art and not a science." See Alexander George, Bridging the Gap: Theory and Practice in Foreign Policy (US Institute of Peace Pr. 1993) at 8; Charles Lindblom, "The Science of 'Muddling Through"” (1959) Publ. Admin. Rev. 79.
} 
Changes in international institutions often develop in response to crises. The First and Second World Wars led to a substantial overhaul in international governance. Likewise, climate change might unfold as another major global crisis and another opportunity to reform international institutions substantially, inasmuch as the perception of climate change leads to a solid engagement of all nations to furthering international cooperation. Yet, many other crises lead only to incremental reforms. Recounting the reactions to the NATO intervention in Kosovo, Hilary Charlesworth described how our focus on crises rather than on everyday situations "diverts attention from structural issues of global justice" and "promotes a narrow agenda for international law."124 While political "astigmatism" 125 is perhaps unavoidable, Charlesworth insists that we, international lawyers, "are ourselves exercising a form of power" 126 - if only by accepting particular political frameworks, such as climate migration, and thus often avoiding a more genuine discussion of underlying structural issues. It is one of the main objectives of this book to shed light on the many structural issues underpinning climate migration as a perceived "crisis," and thus to explore some possible, realistic options for addressing these structural issues rather than seeking to superficially "solve" it.

Despite its essential flaws, the concept of climate migration has attracted considerable public attention and it has triggered important political debates. Climate migration is a weak analytical concept, but it has a particularly strong political currency. Whereas it is important to understand that an individual protection of "climate migrants" cannot and probably should not be established on its own, it remains that there exists a social and political demand for reforms centred on the concept of "climate migration." More might after all be lost than gained if a concept with great political currency, hence likely to trigger political reforms in governance fields arguably in dire need for such reforms, was rejected "just" because of its analytical shortcomings. Rather, one ought to identify possible ways to mobilize the concept of climate migration within compelling political arguments that could support progress in international law.

124 Hilary Charlesworth, "International Law: A Discipline of Crisis" (2002) 65 Mod. L.Rev. 377 at 382, 386.

125 Michael Reisman, "International Incidents: Introduction to a New Genre in the Study of International Law" in Michael Reisman and Andrew Willard, eds., International Incidents: The Law that Counts in World Politics (Princeton U.P. 1988) 3 at 19.

126 Charlesworth, n.125, at 388. 
It must appear clearly at this point that this book does not approach the concept of "climate migration" as the name of a particular phenomenon, or otherwise a concept of great analytical value. "Climate migration" is not used in the following to relate to any essential category of migrants, to any particular scenarios of human mobility, or to any particular form of vulnerability requiring distinct policies. I rather use this term to talk about a broad nebula of political discourses and arguments which have built a significant momentum in recent years, hence, possibly, creating opportunities for reforms in global governance.

\section{POLITICAL DISCOURSES ON “CLIMATE MIGRATION"}

The law of causality ... is a relic of a bygone age, surviving ... only because it is erroneously supposed to do no harm. ${ }^{127}$

Knowledge is mostly dual use. It can be deployed by social forces of both dominance and emancipation. ${ }^{128}$

In philosophy like in law, accounts of causation have led to endless debates that have not always been very helpful. ${ }^{129}$ Causation matters, however, because it defines policy levers that can be used and obligations that can be invoked. Successive concepts of "economic," "environmental" or "climate" "refugees" hinted at similar issues - the lack of effective protection for most forced migrants in existing international law - but they shed light on different policy levers and on the obligations of different actors by attributing forced migration, respectively, to global economic inequalities, environmental degradation, or climate change.

Some authors have followed Russell's rejection of causal discourses as potentially harmful, or otherwise as a suspicious political manoeuvre. ${ }^{130}$ Different forms of political utilization are possible, carried out by

127 Bertrand Russell, "On the Notion of Cause" (1912) 13 Proc. Aristotelian Society 1 at 1 .

128 B.S. Chimni, "The Birth of a 'Discipline': From Refugee to Forced Migration Studies" (2009) 22 J. Refugee Stud. 11 at 13-14.

129 Christopher Hitchcock, "Causation" in Martin Curd and Stathis Psillos (eds.), The Routledge Companion to Philosophy of Science (Routledge, 2008) 317 at 235; H.L.A. Hart and Tony Honoré, Causation in the Law, 2nd ed. (O.U.P. 1985).

130 For Nicholson, for instance, normative concerns "are at risk of playing a performative role politically - being used and abused to further certain political agendas." Nicholson, n.57, at 154-5. 
different actors; in B.S. Chimni's terms, (causal) knowledge can be deployed for dominance as well as emancipation. Despite significant risks that arbitrary causal claims on "climate migration" may be used in the pursuit of undesirable goals such as repressive measures of border control, such claims can also be mobilized in support of progress of international cooperation, in particular, toward a stronger international solidarity and responsibility.

\section{A. Objective of this Book}

The concept of climate migration connects two very different fields of international cooperation. On the one hand, climate change is seen as a "key category [of concern] of the twenty-first century."131 Public interest in the topic is clearly reflected by the large participation in dedicated international events: 108 heads of state and government (an unbeaten historical record) met at the 1992 Rio Conference on Environment and Development ("Earth Summit"). The UN Framework Convention on Climate Change (UNFCCC), adopted at the Earth Summit, has since been ratified by 195 states. About 45,000 activists, journalists and diplomats gathered at the 2009 Copenhagen conference on climate change. ${ }^{132}$ Although local initiatives are developing, climate change still appears mostly as a matter for intergovernmental cooperation. Yet, states have recognized an "ambition gap" between their collective objective of mitigating climate change and their specific individual commitments. ${ }^{133}$

On the other hand, migration is generally considered a domestic political concern rather than a matter for international institutions to regulate. There is no international agency in charge of protecting migrants. ${ }^{134}$ The international conventions protecting migrant workers, stateless persons, and refugees are among the least ratified of UN human

131 John Urry, Climate Change and Society (Polity, 2011) at 24.

132 Dana Fisher, "COP15 in Copenhagen: How the Merging of Movements Left Civil Society Out in the Cold" (2010) 10:2 Glob. Envtl Pol. 11. See also Heike Schroeder and Heather Lovell, "The Role of Non-Nation-State Actors and Side Events in the International Climate Negotiations" (2012) 12:1 Climate Pol'y 23.

133 See e.g. Decision 1/CP.20, Lima Call for Climate Action (2014) 6th recital; Decision 1/CP.19, Further advancing the Durban Platform (2013), para.1; Decision 1/CP.17, Establishment of an Ad Hoc Working Group on the Durban Platform for Enhanced Action (2011), para.7.

134 The International Organization for Migration (IOM), which is not part of the UN system, does not have a protection mandate. 
rights conventions. ${ }^{135}$ Internal migrants are protected by the Guiding Principles on Internal Displacement, a soft-law document presented before the UN Commission on Human Rights in $1998^{136}$ - not a formal source of international law. Despite some developments at the regional level, ${ }^{137}$ there is no universal convention for the protection of internal migrants. Nor does any particular international norm regulate planned displacement and resettlement, except for the internal rules adopted by multilateral banks for their own operations. ${ }^{138}$

Climate change and migration also involve different epistemic communities with very distinct mind-sets. Having literally a planet to save (or, at least, its population), climate change scholars do not shy away from an objective of "[t]ransforming governance and institutions."139 Responding to climate change could justify reforms in virtually every field of governance, from energy to transport, from land-use to food production, and from human rights protection to poverty reduction. It could lead to a profound overhaul in global governance generally. By contrast, migration scholars are by and large on the defensive. The refugee regime lacks vitality, but it is largely feared that, in present political circumstances marked by a latent xenophobia, any substantive reform could end up narrowing down the hard-fought international refugee protection - the sole exception to states' sovereign rights to control their borders.

Could something valuable be gained by connecting climate change and migration? Could the political momentum gathered in reaction to climate change reverberate on the way we conceive of the international governance of migration? Could this help advance the human rights of migrants? This book argues that the great amount of public attention triggered by the concept of climate migration could be an opportunity to

135 The International Convention on the Protection of the Rights of All Migrant Workers and Members of their Families (18 December 1990) has 47 parties; the Convention relating to the Status of Stateless Persons (28 September 1954) has 84 parties; the Convention relating to the Status of Refugees has 145 parties, and its protocol (31 January 1967) has 146 parties. By contrast, the recent Convention on the Rights of Persons with Disabilities (13 December 2006) has 151 ratifications (as of 4 December 2014).

136 E/CN4/1998/53/Add2, 11 February 1998.

137 See Ch. 3, section I.C.

138 See e.g. the World Bank's Operational Policy and Bank Policy 4.12 on "Involuntary Resettlement."

139 Frank Biermann et al., "Transforming Governance and Institutions for Global Sustainability: Key Insights from the Earth System Governance Project" (2012) 4 Current Opinion in Envtl Sustain'y 51. 
push for a broad range of reforms in international governance. A great challenge is however that obvious inconsistencies in certain arguments put the concept of climate migration at great risk of being seized upon to promote illiberal objectives, in particular repressive migration policies. Knowledge, again, can be deployed to promote different - even clearly opposite - political objectives.

The vagueness of the concept of climate migration is particularly prone to permit its use in favour of very different sets of policies. First, this concept might be invoked to illuminate, in general terms, some of the discrepancies between a world of sovereign states and a cosmopolitan ethos, thus calling for more consistent humanitarian cooperation. Secondly, in particular when approached as a form of forced migration outside the refugee regime, climate migration may be used to plead for some progress in the international governance of migration, in particular an extension of international protection. Thirdly, "climate migrants" may be seen as the human face of climate change ("sinking" islands have a lot in common with the popular representation of the polar bear floating on a small piece of melting ice in a vast ocean), highlighting the need for international cooperation to "prevent dangerous anthropogenic interference with the climate system." 140 Alternatively, the impact of climate change on migration can be utilized to reframe states' interests, either in terms of national economic interests or national security, through arguments that may for instance call for repressive border controls or through a more exploitative management of international labour migration.

This book seeks to determine whether and, if so, how the political momentum created by the concept of climate migration may spur progress in international governance. Therefore, it is not a book on how existing international law applies or should apply to "climate migration" as a phenomenon - questions fraught with conceptual issues, given the indeterminacy of the concept of climate migration - but on how the political concept of climate migration may contribute to triggering new developments relating to international governance. In particular, this book comprises an analytical reflection about how existing arguments related to climate migration are likely to impact the relevant international governance regimes (for instance: "Is climate migration a helpful concept in framing effective responses to the adverse social impacts of climate change, to the vulnerability of migrants, to the need for consistent institutions imbedding international solidarity, or in framing states' interests?"). It also develops a normative reflection about how best to

140 UNFCCC, art.2. 
approach climate migration in order to facilitate progress in international cooperation.

This analysis largely follows constructivist premises that see international law as the object of continuous transnational deliberations going well beyond states' pre-determined "interests." By engaging in a world of political arguments on international governance, a step is made to bridge the gap between academia and practice (be it the determination of policies by decision-makers, or the practice of advocacy by many other influential actors), based in particular on the understanding that "[i]t is on the framing of issues that academics are likely to make their most significant contribution to policymaking." 141 This book constitutes a sceptical reflection on the framing of "climate migration" as an issue that needs to be addressed through global governance - rather than climate responsibility or the protection of the rights of migrants.

The normative arguments that follow are, by necessity, based on particular ethical premises which consist in particular in a broad internationalist ethos. It is accordingly accepted that the wellbeing of all individuals should be the main objective of global governance, prevailing over (although without necessarily neglecting) national interests. In this perspective, the progress of international governance is constituted by steps toward more effective responses to issues of global concern. Throughout this book, it appears that a lack of cooperation between states is at the core of the issues reflected in the debate on climate migration: insufficient international assistance is provided when a state is unable to protect the population under its jurisdiction (for instance in the case of a natural disaster); international migration is "managed" by putative states of destination with little consideration to the rights of migrants and the economic stakes for the sending states and communities; and, despite alarming warnings from climate scientists, states have not taken sufficient measures to prevent an increasingly dangerous interference with the climate system. At the core of these issues lies the uncritical understanding that states should follow pre-determined and unnegotiable "interests" - constituted alternatively by economic interests or national security. Throughout this book, climate migration appears as the symbol of our need to reconsider global governance and to adapt it to a changing climate.

141 Janice Stein, in Stephen Krasner et al., "Autobiographical Reflections on Bridging the Policy-Academy Divide" (2009) 22 Cambridge Rev. Int'1 Aff. 111 at 121 . 
This book involves multiple disciplines: beyond international law and international relations, which constitute the core methodology, the analysis involves some insights from communication studies, political sociology, psychology, and moral philosophy, among others. In addition, the topic spans different fields of study relating to humanitarian assistance, internal and international migration, climate change, and security. This variety of sources and disciplines, which inevitably constitutes a challenge, is essential to the objective of assessing the political opportunities arising from political discourses on "climate migration."

\section{B. The Power of Ideas}

An invasion of armies can be resisted; an invasion of ideas cannot be resisted. ${ }^{142}$

I've seen situations in which the Secretary has been dealing with absolute junk when he should be working some really significant issue. I've always wondered why. ${ }^{143}$

Assessing the potentialities of political discourses on "climate migration" requires some preliminary understanding of how global governance evolves. There is no room here for a comprehensive literature review, but it is worth presenting a brief overview of the most relevant theories and concepts as a general background on which the following chapters build.

One of the most relevant theories was developed, at the intersection between international law and international relations, regarding the so-called "norm entrepreneurs." According to Ian Johnstone, international norms "shape through interaction within and between states, and in a transnational process that involves representatives of NGOs, the private sector, and officials of international organizations, as well as states."144 Martha Finnemore and Kathryn Sikkink retraced the three phases of the "life cycle" of norms. During the first phase, or "emergence," norm entrepreneurs play a central role in persuading critical states to adopt a new norm. During the second phase, "cascade," some powerful states and other international actors progressively impose the new norms to other

142 Victor Hugo, The History of a Crime, T.H. Joyce, trans. (Adelaide University, 2014), Ch. X.

143 A "well-informed individual high in the [US] federal executive branch", cited in Kingdon, n.1, at 2.

144 Ian Johnstone, "The Secretary-General as Norm Entrepreneur" in Simon Chesterman, ed., Secretary or General: The UN Secretary-General in World Politics (C.U.P. 2007) 123 at 127-8. 
states. Lastly, the third phase consists in the "internalization" of norms by bureaucracies. ${ }^{145}$ While Finnemore, Sikkink and Johnson conceived norm entrepreneurs as individual actors with organizational platforms, later studies have conflated the two into a notion of collective norm entrepreneurs (e.g. international or regional organizations, states, or nongovernmental organizations). ${ }^{146}$ Whether individual or collective actors, an essential characteristic of norm entrepreneurs is that they are relatively powerless - unable to coerce critical states into adopting particular norms. Norm entrepreneurship is confined to the sphere of ideas. It is through persuasion, not power, that norm entrepreneurs achieve to advance new ideas on international agendas and, thus, to trigger changes to international governance.

Public policy studies have developed similar reflections, although with generally a greater emphasis on domestic governance. Policy entrepreneurs can be constituted by a large range of actors who can play a role in setting the agenda, from political figures to domestic or international civil servants, activists, the media, and researchers. ${ }^{147}$ Theories of policy entrepreneurship distinguish four concomitant processes: agenda setting, alternative specification, decision, and implementation. ${ }^{148}$ Most public policy studies view public policy decisions as incremental steps rather than based on a comprehensive rational analytical process. ${ }^{149}$ Interesting insights for policy entrepreneurship come from the "garbage can" model of organizational choice, first developed by Michael Cohen and co-authors, which approaches organizations as a "collection of choices looking for problems, issues and feelings looking for decision situations in which they might be aired, solutions looking for issues to which they might be the answer, and decision makers looking for work." ${ }^{150}$ Adapting this organizational model to American public policies, John Kingdon

145 Martha Finnemore and Kathryn Sikkink, "International Norm Dynamics and Political Change" (1998) 52:4 Int'l Organization 887.

146 See e.g. Margaret Keck, Activists beyond Borders: Advocacy Networks in International Politics (Cornell U.P. 1998); Michael Barnett and Martha Finnemore, Rules for the World: International Organizations in Global Politics (Cornell U.P. 2004).

147 See ibid., at 122; Michael Mintrom and Phillipa Norman, "Policy Entrepreneurship and Policy Change" (2009) 37:4 Policy Stud. J. 649.

148 Kingdon, n.1, at 2-3.

149 See in particular Michael Hayes, Incrementalism and Public Policy (Longman, 1992); Aaron Wildavsky, The Politics of the Budgetary Process (Little, 1979).

150 Michael Cohen, James March and Johan Olsen, "A Garbage Can Model of Organizational Choice” (1972) 17 Admin. Sci. Q. 1 at 2. 
distinguishes three streams: "(1) problem recognition, (2) the formation and refining of policy proposals, and (3) politics." 151 Accordingly, a "policy window" - a rare political opportunity for reform - occurs when the three streams can be coupled and a political momentum attaches a "solution" to a "problem."152

Because arguments are central to the work of norm or policy entrepreneurs, this book also needs to build on the insights of research that aim to explain why political arguments fail or succeed. ${ }^{153}$ Neta Crawford suggests that social action extends on a long continuum from the rare circumstances where there is no or little place for argument (physical coercion), to ideal-speech situations where "there is only argument."154 On this continuum, most political arguments are made in imperfect settings for social deliberation, where rational arguments interact with emotions, identity building and partial individual commitment. To assess the prospects of political advocacy, much can consequently be learned from a host of sociological studies, ranging from studies of social movement and mobilization, ${ }^{155}$ to psychological studies. ${ }^{156}$ The observation that "[o]ne way a communication can reinforce the acceptance of new beliefs is to arouse and then alleviate emotional tension," 157 for instance, is directly relevant to the analysis of alarmist discourses on "climate refugees." 158

Acknowledging these insights, theories of norm or policy entrepreneurship converge to recognize that the ability of an argument to

151 Kingdon, n.1, at 87.

152 Ibid., at 88.

153 For a review, see Corneliu Bjola and Markus Kornprobst, "Introduction: The Argumentative Deontology of Global Governance" in Corneliu Bjola and Markus Kornprobst, eds., Arguing Global Governance (Routledge, 2011) 1.

154 Neta Crawford, "Homo Politicus and Argument (Nearly) All the Way Down: Persuasion in Politics" (2009) 7 Perspectives on Politics 103 at 107. See also Thomas Risse, "Let's Argue!': Communicative Action in World Politics" (2000) 54 Int'l Organization 1.

155 See e.g. Doug McAdam, John McCarthy and Mayer Zald, eds., Comparative Perspectives on Social Movements: Political Opportunities, Mobilizing Structures, and Cultural Framings (C.U.P. 1996) 1.

156 See in particular Neta Crawford, "The Passion of World Politics: Propositions on Emotion and Emotional Relationships" (2000) 24:4 Int'1 Security 116. 157 See e.g. Seymour Epstein, "Integration of the Cognitive and the Psychodynamic Unconscious" (1994) 49:8 Am. Psychologist 709; Carl Hovland, Communication and Persuasion: Psychological Studies of Opinion Change (Yale U.P. 1953) at 270.

158 The role of fears in political discourses on "climate migration" is discussed in Ch. 3, section III.A, and in Ch. 5. 
succeed (i.e. persuade and generate reforms) depends only very partly on its logical validity. Individuals certainly try to avoid the psychological discomfort of ideas that are too obviously inconsistent with pre-existing views, but this is only one motivation out of many, and not necessarily a decisive one. ${ }^{159}$ More than from its internal consistency, the success of an argument depends on its ability to connect to an audience's pre-existing set of ideas - an intellectual background that has variously been referred to as "enchantment" (Plato), "governmentality" (Foucault), "common lifeworld" (Habermas), ${ }^{160}$ "cultural resonance,"161 or even "national mood."162

All of these theoretical tools have been developed on the basis of retrospective case studies, in order to explain observed phenomena, whereas the objective of this book involves a prospective use of these theories to predict possible outcomes. There is no logical obstacle to applying a valid explanatory theory to a more predictive endeavour. Social science theories never allow exact predictions, as they never fully comprehend human agency, but valid social science theories can help determine more or less probable trends of social or political changes. ${ }^{163}$ Yet, the predictive use of social science theories can be challenging. While historical studies often focus on successful actors or events and may conveniently omit the many others who had little distinctive impact, ${ }^{164}$ a predictive analysis is bound to identify a variety of competing actors who are deploying diverging arguments at the same time - all the more so on the basis of a vague concept such as "climate migration," on which very different political discourses have been elaborated. Far from any self-confident "history of the future," this book can only map the argumentative battlefield, identify the different contenders and their respective strengths, and assess, on the basis of the resources available to each contender, the odds that particular outcomes follow particular strategies.

\footnotetext{
159 Leon Festinger, A Theory of Cognitive Dissonance (Stanford U.P. 1962).

160 See Crawford, n.155, at 110; Risse, n.155, at 12, 14.

161 See e.g. Mitch Berbrier, "Half the Battle': Cultural Resonance, Framing Processes, and Ethnic Affectations in Contemporary White Separatist Rhetoric" (1998) 45 Social Probs 431.

162 Kingdon, n.1, at 146.

163 Ibid. at 206-8.

164 Lesley Wexler, "The International Deployment of Shame, Second-Best Responses, and Norm Entrepreneurship: The Campaign to Ban Landmines and the Landmine Ban Treaty" (2003) 20 Ariz. J. Int'l \& Comp. L. 561.
} 


\section{Four Argumentative Narratives}

Theories on argumentation and norm entrepreneurship can help to explain how discourses of climate migration have been able to attract public attention despite the flaws presented above. Consistency is only one of many elements that allow an argument to succeed. It is one of the main findings of this book that arguments on climate migration have an exceptional capacity to arouse interest in spite of their essential conceptual and normative shortcomings. There is no essential reason why migrants should be more strongly protected than other vulnerable people (e.g. those unable to migrate), but migrants just attract more attention, if only because of the (unfounded) fear that they may be approaching or threatening "us." Nor is there any reason to focus on climate migrants specifically, among the many forced migrants triggered by the interaction of interrelated environmental, economic, social, political and demographic factors - but anything that relates to climate change, being new hence justifying new concerns, is conducive of greater engagement. Through the analysis conducted in this book, the concept of climate migration appears as a magical recipe through which the deep-rooted fears of migration are blended with the existential concerns raised by climate change, triggering public anxiety and fuelling demand for a "solution."

An issue is that there is no obvious and simple "solution" to "climate migration." The vagueness of the concept of "climate migration" allows a number of diverging discourses to be elaborated, which frame the "problem" in different ways and identify different "solutions." Thus, for some norm entrepreneurs, climate migration appears as mainly a humanitarian issue. For others, it is an issue of forced migration or, perhaps, migration in general. For yet another group of advocates, climate migration is about responding to the impacts of climate change, and it is in particular a responsibility for industrial states, on the ground of their past and present greenhouse gas emissions. Lastly, some political actors see climate migration as mainly a question of adapting national policies to changing states' interests, in particular in order to protect themselves from what are perceived as growing threats. And yet each of these groups contains its own dissensions.

The outlines of this book are built on this distinction between alternative narratives: the humanitarian narrative, the migration narrative, the responsibility and a set of pragmatic narratives (focusing on states' 
interests). ${ }^{165}$ Each narrative is characterized by a broader ultimate objective that can be served by a variety of a specific set of arguments on "climate migration." In each case, climate migration is a façade for pre-existing and more substantial arguments.

The humanitarian narrative, explored in Chapter 2, construes climate migration as primarily an issue of human suffering, in particular within developing states. This narrative pleads for international cooperation for the realization of human rights, including social and economic rights. Institutionally, this narrative is of particular interest for international organizations ${ }^{166}$ and $\mathrm{NGOs}^{167}$ that deal specifically with international development or humanitarian assistance. Each state must protect the human rights of individuals within its jurisdiction, but circumstances such as a natural disaster may result in a state not being able to effectively protect its population. "Climate migration," as it is then construed, may be induced by inadequate protection in the place of origin, and it may also cause greater protection needs during displacement or at the place of destination. Chapter 2, therefore, explores existing norms on human rights protection and humanitarian assistance, and it suggests some reflections on the prospects and dangers of a humanitarian argument for the protection of "climate migrants."

The migration narrative (Chapter 3) construes climate migration in relation to the specific vulnerability of migrants, in particular forced migrants who cross international borders. Its advocates feature in particular migration scholars (e.g. Walter Kälin, Jane McAdam) and two international agencies: the office of the UN High Commissioner for Refugees (UNHCR) and the International Organization for Migration (IOM). The narrative often relates to an analogy, either explicit or not, between the situation of international migrants falling within the scope of the international protection of refugees and other forced migrants crossing international borders. In this context, "environmental" or "climate refugees" come to replace arguments previously framed in relation to "economic refugees," as the focus turns from development to climate change adaptation. Beyond this analogy, Chapter 3 shows that the concept of climate migration could be used to recall the human rights of

165 Cf. Chloe Vlassopoulos, "Institutional Barriers to the Recognition and Assistance of Environmentally Forced Migrants" in Afifi and Jäger, n.88, 17.

166 See e.g. UNDP, Human Development Report 2007/2008: Fighting Climate Change; Human Solidarity in a Divided World (Macmillan, 2007); Addressing Climate Change and Migration in Asia and the Pacific (ADB, 2012).

167 See for instance Christian Aid, n.19. 
all migrants - including "voluntary" migrants and internal migrants - as human beings.

The responsibility narrative (Chapter 4 ) approaches climate migration as fundamentally the portent of times to come - the canary in the coalmine - in the age of climate change. This narrative is produced for instance by climate change scholars (e.g. Frank Biermann, Norman Myers), environmental NGOs (e.g. Environmental Justice Foundation, Equity BD), and some international institutions (UNEP, UNFCCC), with the support of some developing states (in particular the Alliance of Small Island States, AOSIS). These actors call for reinforced efforts to mitigate climate change and to promote climate change adaptation, including through specific protection mechanisms for "climate migrants." This narrative often suggests that industrial states have specific, causal responsibility vis-à-vis "climate migrants," which may translate into an obligation to welcome some migrants within their territory or to cede land for collective resettlement. Chapter 4 argues that the responsibility of industrial states justifies compensation (i.e. unconditional financial transfer) of the states most affected by climate change, but not the imposition of particular obligations (such as standards of protection for "climate migrants") onto those states: responsibility does not justify interference in the domestic affairs of the injured states.

Lastly, Chapter 5 explores transversal pragmatic narratives. By contrast to the three previous moral or somewhat "idealistic" narratives, pragmatic ones contemplate climate migration in the view of states' interests. They deal with protection needs, migration and climate change, sometimes in the same discourses, but, unlike the three previous narratives, their argument is not mainly about ethical duties but about self-interest. Yet, these narratives are plural in nature because there are essentially incompatible views about what states' interests are in relation to climate change, migration, and climate migration. A distinction can in particular be drawn between a somewhat intuitive narrative based on states' economic interests and another one, more prominent, building on considerations of national security, conveyed in particular by think tanks, lobbies and researchers, and through discussions on climate change held within the UN Security Council. Through an exploration of the various pragmatic narratives, it appears that states" "interests" can be construed in various ways in relation to both climate change and migration. On this ground, Chapter 5 argues that proper consideration for states' complex interdependence could give rise to an alternative pragmatic narrative, more prone to justify international cooperation and thus to address the issues highlighted by the concept of climate migration. 
These four narratives are all-encompassing although perhaps not perfectly exhaustive. Further distinctions could be made, for instance within the humanitarian narrative, between what relates to domestic human rights protection, to international aid to development, and to humanitarian assistance following natural disasters. Likewise, a "refugee narrative" could be singled out from the broader "migration narrative." It could have been worth further discussing the managerial discourse on "migration and development" or "migration as adaptation," only briefly referred to within pragmatic narratives on national economic interests, given its increasing discursive importance within certain spheres. ${ }^{168}$ Despite these caveats, related to constraints of length and time, it is believed that the analysis does not leave too substantial dark areas likely to render it invalid.

It is also important to note at the outset that all of these narratives have in common to be narratives about "climate migrants," but never to be produced by self-identified "climate migrants." Beyond "barriers of simple participation," 169 the complete absence of self-identified "climate migrants" has to do with the indirect causal relations between climate change and migration: populations of migrants do not generally perceive themselves as displaced because of climate change. ${ }^{170}$ Yet the total absence of self-identified "climate migrants" from the debate has often remained remarkably unremarked. In these circumstances, the concept of climate migration has been developed as essentially a discussion about our imagined Other, a discussion that certainly tells us more about ourselves - our fears of others or our desires for reforms - than about any "Other." The concept of "climate migration" is thus an occasion to re-discover some of the fundamental tensions and paradoxes in the dominant perspectives on contemporary global governance, in particular between the demand for universal human rights protection and the frequent disregard of migrants' dignity, and between a well-established principle of responsibility and the international responses to climate change.

Each of the narratives on climate migration relates to a specific epistemic community, and builds in relative isolation from other narratives. A dichotomy opposes self-centred pragmatic narratives, relating in

168 See in particular Romain Felli, "Managing Climate Insecurity by Ensuring Continuous Capital Accumulation: 'Climate Refugees' and 'Climate Migrants"” (2013) 18:3 New Pol. Econ. 337.

169 Crawford, n.155, at 118.

170 See for instance, Jane McAdam and Maryanne Loughry, “'We Aren’t Refugees"” (2009) Inside Story; McNamara and Gibson, n.51. 
their dominant version (national security narrative) to fears, and more altruistic narratives, building in particular upon compassion (humanitarian narrative), empathy (migration narrative) or guilt (climate change narrative). As they do not agree on a unique "solution" or even on a particular framing of a "problem" (one of human vulnerability, migrants" rights, responsibility, economic development, or international security), the norm entrepreneurs using the concept of climate migration are unlikely to merge within a unique advocacy coalition. Yet, these narratives build on a common lexicon and often address the same audiences, thus necessarily interacting in a confusing patchwork of advocacies. This interaction raises new theoretical questions. Advocacy has typically been conceived in a "vertical" relation whereby powerless non-state actors try to convince more powerful state actors to adopt a specific conduct. In the present case, however, part of the debate inevitably occurs horizontally: norm entrepreneurs compete, on a narrow conceptual ground, to impose arguments that diverge and sometimes conflict one with another. Whether or not these narratives are exclusive by nature, the advancement of one diverts attention from the others, thus impeding the realization of alternative political agendas. A unique concept can hardly be related to more than one substantial issue in an effective political discourse.

These narratives employ different argumentative strategies, with different prospects of success. The pragmatic narrative of national security, in particular, has a number of strategic advantages over the other narratives. Rather than the desire to help, the national security narrative exposes the necessity to protect oneself: the language of interests is generally stronger than the invocation of moral obligations, and fears are a remarkably more compelling emotion than compassion, empathy, or guilt. Policies of national security are often identified (wrongly) as significantly cheaper than the pre-emptive solutions suggested by the three other narratives, which receive little support in a context of aid fatigue and never-ending economic crises. ${ }^{171}$ It is profoundly disturbing to consider that the security narrative might even benefit from the social dynamics that other narratives initiate to promote "solutions" in sharp contrast to the objectives of furthering international cooperation with regard to humanitarian cooperation, the protection of the rights of migrants, or climate responsibility.

In these circumstances, this book submits that advocates of international humanitarian cooperation, of the rights of the migrants, and of

171 See generally Gregory White, Climate Change and Migration: Security and Borders in a Warming World (O.U.P. 2011). 
climate change mitigation should more carefully consider the risk that their discourse could come in support of a security narrative. A possible response would be to express moral arguments in a hybrid (moral and pragmatic) narrative, which would essentially frame states' interests in a roughly moral way. Thus, Chapter 5 shows that, in a complex and interdependent world, it might be in states' own, well-understood interests not to fight against migrants, but against climate change, and to facilitate international development rather than seeking immediate economic gains. In the long term, national security and prosperity cannot be provided by repression alone, but only by addressing structural social tensions. No state can durably flourish in isolation, ignoring human suffering in the rest of the world, denying rights to migrants, but still continuing to interfere dangerously with the climate system. 